\title{
Karadut (Morus nigra) suyunda rutin ve toplam fenolik bileşiklerin Isıl parçalanma kinetiği
}

\section{Thermal degradation kinetics of rutin and total phenolic compounds in black mulberry (Morus nigra) juice}

\author{
Cemre SERNIKLi' ${ }^{1}$, Çetin KADAKAL ${ }^{1 *}$ iD \\ ${ }^{1}$ Pamukkale Üniversitesi, Mühendislik Fakültesi, Gıda Mühendisliği Bölümü, 20160, Kınıklı, Denizli-TURKEY
}

\section{To cite this article:}

Sernikli, C. \& Kadakal, Ç. (2020). Karadut (Morus nigra) suyunda rutin ve toplam fenolik bileşiklerin ısıl parçalanma kinetiği. Harran Tarım ve Gıda Bilimleri Dergisi, 24(3): 290-300.

DOI:10.29050/harranziraat.687653

\section{Address for Correspondence: Çetin KADAKAL \\ e-mail: \\ ckadakal@pau.edu.tr}

Received Date:

13.02.2020

Accepted Date:

07.07.2020

(c) Copyright 2018 by Harran University Faculty of Agriculture. Available on-line at www.dergipark.gov.tr/harranziraat

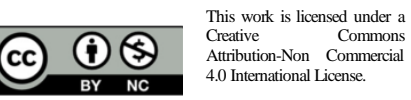

\section{öz}

Bu çalışmada, karadut suyunun $70-95{ }^{\circ} \mathrm{C}$ sıcaklık aralığında ve farklı ısıtma periyotlarında (0, $5,10,15,20$ ve $30 \mathrm{dk}$.) Isıl işleme tabi tutulmasıyla karadut suyunun rutin ve toplam fenolik içeriğinde meydana gelen değişimler belirlenmiştir. Bu amaçla taze karadut meyveleri öncelikle meyve suyunu işlenmiş ardından ısıl işlem uygulaması yapılmıştır. Karadut suyunda rutin tayini sIVı kromatografik, toplam fenolik tayini ise spektrofotometrik yöntemle belirlenmiştir. Isıl işlem sırasında, karadut suyunda ısıl işlem uygulamasına bağlı olarak rutin ve toplam fenolik içeriğindeki bozunmalar birinci dereceden kinetik modele uymuştur. Rutin ve toplam fenolik reaksiyonların sıcaklık bağımlılığı Arrhenius ilişkisi ile tanımlanmıştır. Rutin ve toplam fenolik içeriğinin $70-95{ }^{\circ} \mathrm{C}$ sıcaklık aralığındaki aktivasyon enerjileri sırasıyla 50.53 ve $34.89 \mathrm{~kJ} \mathrm{~mol}^{-1}$ bulunmuştur.

Anahtar Kelimeler: Fenolik, Karadut, Meyve suyu, Parçalanma kinetiği, Rutin

\section{ABSTRACT}

In this paper, the effect of heat treatment on rutin and total phenolic compounds in black mulberry juice with the heating periods $(0,5,10,15,20$ and $30 \mathrm{~min})$ at temperatures ranging from 70 to $95{ }^{\circ} \mathrm{C}$ is analyzed and experimental results are presented. Firstly, fresh black mulberry fruits were processed to black mulberry juice and then thermal treatment is performed. Liquid chromatographic and spectrophotometric methods were used for the analysis of rutin and total phenolic compounds, respectively. During thermal processing, degradation of rutin and total phenolic compounds in black mulberry juice were fitted to a first-order reaction kinetic model. Arrhenius relationship was used for the description of temperature dependence of reaction. Activation energies for rutin and total phenolic compounds between 70 to $95{ }^{\circ} \mathrm{C}$ were found as 50.53 and $34.89 \mathrm{~kJ} \mathrm{~mol}^{-1}$, respectively.

Key Words: Phenolic, Black mulberry, Juice, Degradation kinetics, Rutin

\section{Giriş}

Moraceae familyasına ait olan karadutun (Morus nigra) (Tarko ve ark., 2014; Dinçer ve ark., 2016) anavatanı Hindistan, Çin ve Japonya'dır. Karadut ayrıca Kuzey İran, Suriye, Suudi Arabistan, Yunanistan, Fransa, İtalya, İspanya, Rusya, Güney Asya, ABD, Avustralya, Akdeniz Ülkeleri, Orta
Avrupa ve kısmen Kuzey Avrupa'da da iyi yetişir (Davis, 1987).

Biyoaktif bazı bileşiklerin iyi bir kaynağı olan karadutun önemi içeriğindeki toplam fenolik ve $C$ vitamini komposizyonuna ilaveten (Fazaeli ve ark., 2013; Sánchez-Salcedo ve ark., 2015) protein, karbonhidrat, yağ, lif, mineral madde (özellikle kalsiyum, demir, fosfor) ve suda çözünür 
vitaminler (tiamin, riboflavin, nikotinik asit ve askorbik asit) gibi besleyici değerlerinden kaynaklanmaktadır (Vankatesh ve Chauhan, 2008). Karadut meyvesi keşfedildiği günden beri ilaç (balgam söktürücü, kan şekerini düşürücü, dizanteriyi tedavi edici, ateş ve kan basıncı düşürücü) olarak kullanılmaktadır (Güngör ve Şengül, 2008). Tüm bu özelliklerine ek olarak antioksidan, antienflamatuar ve antimikrobiyal özelliklere sahip karadut meyvesi çeşitli fitokimyasallar içeren fenolikleri de bünyesinde bulundurmaktadır (Gecer ve ark., 2016).

Besleyicilik, fizyolojik ve teknolojik özellikleri nedeniyle önemli bir meyve olan karadut tatlı, hoş bir tada sahiptir. Ancak yumuşak dokusu ve kısa sürede bozulmasından dolayı hasat edilmesi, taşınması ve pazarlanması zor bir meyvedir. Bu nedenle meyve çoğunlukla işlenerek tüketilir (Gerasopoulos ve Stavroulakis, 1997). Türkiye, geleneksel gıda üretim teknikleri konusunda zengin bir birikime sahiptir. Ülkemizde karadut meyvesi taze ve kurutularak tüketildiği gibi pekmez, meyve suyu, marmelat, likör, pestil ve köme gibi çeşitli ürünlere işlenerek de tüketilir (Boranbayeva ve ark., 2014; Tomas ve ark., 2015).

Fenolik bileşikler; fenolik asitler ve flavonoidler olarak iki gruba ayrılmaktadır. Flavonoidler, doğal bitkisel çaylarda, meyve ve sebzelerde bulunan polifenolik antioksidanlardır (Nizamlıoğlu ve Nas, 2015). Fenolik bileşiklerin bazıları, meyve ve sebzelerin lezzet bileşenlerinin oluşumunda, özellikle ağızdaki acılık ve ekşilik gibi iki önemli lezzetin oluşumunda etkilidir. Bazılarıda meyve ve sebzelerin sarı, sarı-kahverengi, kırmızı-mavi renk tonlarını sağlamaktadır (Gökalp ve ark., 1992). Fenolikler, antioksidan, antimutajenik ve antikansirojenik etkilerine ilaveten gen ekspresyonunu değiştirebilme yeteneğine sahiptirler (Nakamura ve ark., 2003; Ercişli ve Orhan, 2008). Türkiye'de yetişen karadut meyvelerinde gerçekleştirilen bir çalışmada toplam fenolik içeriği 1943-2237 mg gallik asit (mg GAE $100 g^{-1}$ ) eşdeğeri (taze ağırlık) olarak belirlenmiştir (Kicel ve ark., 2015).

Flavanoid sınıfının bir glikoziti olan rutin, quercetin ve disakkarit olan rutinozdan oluşur
(Kicel ve ark., 2015; Yıldırım ve ark., 2017). Önemli bir rutin kaynağı olan karadut antioksidan (Korkmaz ve Kolankaya, 2010), antiinflamatuar (Lee ve ark., 2012), nöroprotektif (Yıldırım ve ark., 2017), antihiperglisemik ve antimikrobiyal aktivitelere sahiptir (Kamalakkannan ve Prince, 2006). Rutinin diğer kaynakları karabuğday, soğan, limon, elma, portakal, greyfurt (Attia, 2016) ve çaydır (Kuntic ve ark., 2007). Ancak, önemli bir rutin kaynağı olmasına rağmen beyaz veya karadutlarda rutin üzerine çalışma yok denecek kadar az, rutinin ısıl parçalanma kinetiği konusunda ise hiç çalışmaya rastlanılmamıştır.

Yaklaşık iki aylık hasat süresine sahip karadut meyvesinin kısa bir süre soğukta saklanma imkânı vardır. Bu nedenle meyvenin muhafazasında en önemli yöntem ısıl işlem uygulamasıdır (Maskan ve ark., 2002; Fazaeli ve ark., 2013). Meyve olgunluğu, hasat zamanı, saklama koşulları ve süresi, tüketim öncesi pişirme ve depolama gibi faktörler meyvenin toplam fenolik madde içeriğini etkilemektedir (Gecer ve ark., 2016).

Toplam fenolik analizinde yaygın kullanılan yöntem spektrofotometrik (İnanç ve Yüksel, 2018; Karaman ve ark., 2020) olmasına karşılık rutin analizinde hem spektrofometrik (Kuntic ve ark., 2000) hemde sıvı kromatografik teknikler kullanılır (Daigle ve Conkerton, 1988; Menghinello ve ark., 1999; Li ve Fitzloff, 2001; Leite ve ark., 2001; Pang ve ark., 2009). Ancak yüksek performanslı sıvı kromatografisi (HPLC) hızlı, doğru ve hassas belirleme açısından rutin analizi için tercih edilen yöntemdir.

Gıdalarda teknolojik kontrolün sağlanması ve öngörülen kalitenin sağlanabilmesi açısından gıdalardaki değişimlerin kinetik modellenmesi gereklidir (Van Boekel, 2008). Güvenli gıda üretiminde gıda kalite göstergesi olan bileşiklerin parçalanmadan maksimum seviyede kalabilmesini sağlamak için, gıda prosesleri tasarlanırken ısıl işlem uygulamalarına ilişkin kinetik modellere intiyaç vardır (Avila ve Silva, 1999). Yapılan literatür çalışmasında karadut suyunda rutin ve toplam fenolik bileşiklerin ısıl parçalanması hakkında herhangi bir yayına rastlanmamıştır. Bu çalışmada: 
a) Isıl işlemler $\left(70,80,90\right.$ ve $\left.95^{\circ} \mathrm{C}\right)$ sırasında rutin ve toplam fenolik bileşiklerdeki değişikliklerin belirlenmesi,

b) Karadut suyundaki rutin ve toplan fenolik bileşiklerin $70-95{ }^{\circ} \mathrm{C}$ sıcaklık aralığında farklı süre $(0,5,10,15,20,25$ ve $30 \mathrm{dk}$.) ısıl işleme tabi tutulmasına bağlı olarak bozunma kinetiklerinin belirlenmesi,

c) Kinetik parametrelerin belirlenmesi ile parçalanma reaksiyonlarının tanımlanması (reaksiyon hızı sabiti, reaksiyon derecesi, aktivasyon enerjisi, $Q_{10}$, yarı ömür süresi) amaçlanmıştır.

\section{Materyal ve Metot}

Materyal

Taze karadut meyveleri (Morus nigra), Doğu Karadeniz Bölgesi'nde faaliyet gösteren bir meyve suyu fabrikasından (Gümüssu Gıda Sanayi, Gümüşhane) sağlanmıştır. Hasat döneminde fabrikadan temin edilen yaklaşık $300 \mathrm{~kg}$ taze karadut, Denizli, Pamukkale Üniversitesi Gıda Mühendisliği Bölümüne soğutmalı araç ile transfer edilerek karadut suyuna işlenmiştir.

\section{Karadut suyu üretimi}

Karadut meyvesi öncelikle kir, yaprak ve yabancı maddelerinden uzaklaştırılmıştır. Yabancı maddelerden ayıklama işlemini takiben bir meyve değirmeni yardımı ile öğütülen meyveler (Model KMS6000, Vestel) bez torba içine alınmış ve hidrolik pres (Bucher-Guyer AG, Niederweningen, İsviçre) kullanılarak suyu çıkarılmıştır. Elde edilen karadut suyu, bir filtreden (25 $\mu \mathrm{m}$ gözenek boyutu) geçirilerek cam tüplere (75x10 mm ID) aktarılmış ve ısıl işlem uygulama zamanına kadar 4 ${ }^{\circ} \mathrm{C}$ 'de saklanmıştır.

\section{Isıl işlem uygulaması}

Karadut suyunda rutin ve toplam fenolik içeriğinin ısıl parçalanma kinetiğinin belirlenmesi için 70, 80, 90 ve $95{ }^{\circ} \mathrm{C}$ sıcaklıklar seçilmiştir. Isıtma işleminde, içerisine $25 \mathrm{ml}$ karadut suyu konulan ve termostatik su banyosuna (Model 3047, Kottermann, Hänigsen/Germany) yerleştirilen borcam tüplerinden (üç boyunlu yuvarlak tabanlı bir şişe, $75 \times 10 \mathrm{~mm}$ ID) yararlanılmıştır. Sıcaklık uygulama süresinin tespitinde, termokupl ile ölçülen numune sıcaklıklarının istenen sıcaklığa ulaşması esas alınmıştır. Tüm ısıtma işlemlerinde istenen en yüksek $\left(95^{\circ} \mathrm{C}\right.$ ) sıcaklığa 8 dakikada ulaşılmaktadır. Yaklaşık \%90 doluluk oranına sahip tüplerin kapakları, buharlaşmayı önlemek için sıkıca kapatılarak termostatik su banyosuna yerleştirilmiştir. Meyve suyu örnekleri su banyosunda belli süreler bekletilmiş $(0,5,10,15$, 20, 25 ve $30 \mathrm{dk}$.), sonra sıcak su banyosundan alınarak buzlu su banyosunda hızlı bir şekilde soğutulmuştur. Tüm deneyler üç tekerrür halinde gerçekleştirilmiş ve her bir sıcaklığa ait reaksiyon hızı sabitleri de üç tekerrür için hesaplanmıştır.

\section{Sıcaklık seçimi ve ısıtma süreleri}

Çalışmada kullanılan $70-95{ }^{\circ} \mathrm{C}$ sıcaklık aralığının seçiminde geleneksel ve endüstriyel üretim prosesleri dikkate alınmıştır. Karadut suyu ve meyve suyu konsantresinin endüstriyel üretiminde kullanılan en düşük sıcaklık değeri ısıtma süresine bağlı olarak $70{ }^{\circ} \mathrm{C}$ civarındadır. Geleneksel üretim yönteminde ise şişelenmiş karadut suları açık tip kazanlarda yaklaşık 20-30 dk. kaynar suya bırakılır. Böylece, şişe içindeki karadut suyunun merkezi sıcaklığı yaklaşık 95 ${ }^{\circ} \mathrm{C}$ 'ye ulaşır. Tüm bu uygulamalar dikkate alınarak çalışma için uygulama sıcaklığı $70-95^{\circ} \mathrm{C}$ aralığında seçilmiştir.

\section{Metot}

\section{Toplam fenolik madde analizi}

Karadut suyunun toplam fenolik madde içeriği Folin Ciocalteu spektrofotometrik yöntem kullanılarak belirlenmiştir (Tanner ve Brunner, 1979). Bu amaçla 40, 80, 120, 160 ve 200 ppm konsantrasyonlarda gallik asit çözeltileri hazırlamıştır. $75 \mathrm{ml}$ distile su ile $1 \mathrm{ml}$ numune (seyreltilmemiş) balon jojede $(100 \mathrm{~mL})$ karıştırılarak üzerine $5 \mathrm{ml}$ Folin-Ciocalteu ayıracı eklenmiş ve $3 \mathrm{dk}$. bekletilmiştir. Daha sonra doymuş sodyum karbonat çözeltisi (10 mL, \%20) 
ilave edilerek tekrar iyice çalkalanan içerik saf suyla 100 ml'ye tamamlanmıştır. Elde edilen çözelti, karanlık bir yerde 1 saat bekletildikten sonra UV/VIS spektrofotometre cihazı (T80, PG Instruments, UK) kullanılarak $720 \mathrm{~nm}$ dalga boyunda absorbans okuması gerçekleştirilmiştir. Ölçülen absorbans karşılığı toplam fenolik madde içeriği, deiyonize suda çözünen ve litre başına mg gallik asit eşdeğeri (GAE) olarak ifade edilen standart gallik asit eğrisinden (0-200 mg/L) belirlenmiştir.

\section{Rutin analizi}

Katı faz ekstraksiyonu (SPE) uygulanarak elde edilen örneklerin analizinde Yüksek Basınç Sıvı Kromatografi cihazı (HPLC) kullanılmıştır. Rutin analizinde kullanılan HPLC cihazına ilişkin cihaz özellikleri ve yöntem koşulları Çizelge 1'de verilmiştir.

Çizelge 1. Rutin tayini için sıvı kromatografik koşullar Table 1. Liquid chromatographic conditions for rutin analysis

\begin{tabular}{|c|c|}
\hline HPLC & SHIMADZU (Kyoto/Japan) \\
\hline $\begin{array}{l}\text { Kolon Fırını } \\
\text { Column oven }\end{array}$ & CTO-20A, Sıcaklık $25^{\circ} \mathrm{C}$ \\
\hline $\begin{array}{l}\text { Kolon } \\
\text { Column }\end{array}$ & $\begin{array}{l}\text { C-18 ( } 150 \times 4.6 \mathrm{~mm}, \mathrm{ID}, 5 \mu \mathrm{m} \text { particle } \\
\text { size) SUPELCO }\end{array}$ \\
\hline $\begin{array}{l}\text { Pompa } \\
\text { Pump }\end{array}$ & $\begin{array}{ll}\text { SHIMADZU, } & \text { LC(Liquid } \\
\text { Chromatograpy)-20AD } & \\
\end{array}$ \\
\hline $\begin{array}{l}\text { Degazer } \\
\text { Degasser }\end{array}$ & SHIMADZU, DGU-20A \\
\hline $\begin{array}{l}\text { Detektör } \\
\text { Detector }\end{array}$ & $\begin{array}{l}\text { SHIMADZU, Photo Diode } \\
\text { (PDA) Detector, SPD-M20 AVP; } \\
\text { Dalga boyu: } 220 \mathrm{~nm}\end{array}$ \\
\hline $\begin{array}{l}\text { Sistem Kontrol } \\
\text { System controller }\end{array}$ & SHIMADZU, CBM, 20Alite \\
\hline $\begin{array}{l}\text { Mobil Faz } \\
\text { Mobil phase }\end{array}$ & $\begin{array}{l}\text { İzokratik; } \mathrm{KH}_{2} \mathrm{PO}_{4} \text {-Asetonitril (99:1, } \\
\mathrm{v} / \mathrm{v}) \text {, }\end{array}$ \\
\hline $\begin{array}{l}\text { Akış Hızı } \\
\text { Flow rate }\end{array}$ & $1 \mathrm{ml} \mathrm{dk}^{-1}$ \\
\hline $\begin{array}{l}\text { Enjeksiyon } \\
\text { Injection }\end{array}$ & $20 \mathrm{ml}$ \\
\hline $\begin{array}{l}\text { Program } \\
\text { Programme }\end{array}$ & Shimadzu Software Program \\
\hline
\end{tabular}

\section{Kalibrasyon eğrisinin çizilmesi}

Analizlerde Merck firmasından (Darmstadt, Almanya) sağlanan HPLC saflığındaki metanol ve ekstra saf potasyum dihidrojen fosfat kullanılmıştır. Analizlerde deiyonize su kullanılmıştır. Analitik saflıktaki rutin standardı Sigma firmasından (Sigma Chemical Company,
Deisenhofen-Germany) temin edilmiştir. Kalibrasyon eğrisinin hazırlanmasında mobil faz içerisinde hazırlanan beş farklı konsantrasyondaki rutin standardı kullanılmıştır. Tüm çözeltiler ışığın olumsuz etkilerine karşı koyu renkli cam şişelerde ve buzdolabında saklanmıştır. Rutin standardının stok çözeltisi kullanılarak 5-250 ppm aralığında, pik alanına (mAU) karşı çizilen konsantrasyon ( $\mathrm{mg}$ $\mathrm{L}^{-1}$ ) eğrisinde 5 noktayı kapsayan ve 0.999 korelasyon katsayılı kalibrasyon eğrisi elde edilmiştir. Kalibrasyon eğrisinin hazırlanmasında her bir standart çözeltiyle üç enjeksiyon gerçekleştirilmiştir.

\section{Örnek hazırlama (Katı faz ekstraksiyonu=SPE)}

Karadut bileşenlerinin çoğu, kromatografik belirleme işleminde rutin ile etkileşime neden olur. Bu nedenle, rutinin ayrıştırmasını sağlayan, diğer bileşenlerin ayrışmasına izin vermeyen veya diğer bileşenlerin çoğunu askıya alan Sep-Pak C18 (500 mg) kartuşlu bir SPE numune hazırlama yöntemi kullanılmıştır. Bu amaçla $5 \mathrm{~g}$ karadut suyuna $25 \mathrm{~g}$ deiyonize su eklenerek (Seyreltme faktörü, $F=6) 1 \mathrm{dk}$. boyunca orta hızda bir homojenizatörde karışımın homojen hale gelmesi sağlanmıştır. Karışımın homojenleştirilmesini takiben $14 \times 10^{3}$ rpm'de (Model 2-16, Sigma Bioblock Scientific) $10 \mathrm{dk}$. santrifüj işlemi uygulanmıştır. Rutin ekstraksiyonunda, SPE yönteminde bazı modifikasyonlar yapılmıştır (Cho ve ark., 2000). Sabit fazın aktivasyonunda yıkama sırasında $\mathrm{pH}$ değeri 4.2'ye ayarlanmış eşit hacimli $20 \mathrm{ml}$ metanol-su (v/v) karışımı kullanılmıştır. Sabit faz aktivasyonunun ardından, homojenize edilmiş ve santrifüjlenmiş karadut suyu $(10 \mathrm{~mL})$ sisteme yüklenmiştir. Sisteme yüklenen numune $0.005 \mathrm{M} \mathrm{HCL}$ çözeltisi kullanılarak asitlendirilmiş su (5 mL, pH 4.2) ve ardından $1 \mathrm{ml} \mathrm{dk.}{ }^{-1}$ akış hızında metanol (10 $\mathrm{mL})$ ile elüe edilmiştir. Elüsyonu takiben eluantlar bir şişede toplanarak sıvı faz tamamen uzaklaştırılana kadar evapore edilmiştir. Kalıntının $1 \mathrm{ml}$ mobil fazda çözündürülmesini takiben $0.45 \mu \mathrm{m}$ gözenek boyutundaki filtreden (Schleicher-Schuell, Darmstadt Germany) süzülen filtratın $20 \mu$ l'lik 
kısım rutin analizi için HPLC kolonuna enjekte edilmiştir.

Rutin analizinde $204 \mathrm{~nm}$ dalga boyuna ayarlanan PDA detektörü kullanılmıştır. Analiz için kullanılan mobil faz öncelikle ultrasonik su banyosunda tutulmak suretiyle gazdan arındırılmış, kullanımdan hemen önce de $0.45 \mu \mathrm{m}$ 'lik bir filtreden süzülmüştür. HPLC analizinde mobil faz olarak $0.7 \mathrm{ml} \mathrm{dk}^{-1}$ akış hızında $0.1 \mathrm{~mol} \mathrm{~L}^{-}$ 1 potasyum dihidrojen fosfat $(\mathrm{pH}: 7)$ ve metanol (90:10) (v/v) kullanılmıştır. Rutin konsantrasyonu, elde edilen kromatografik piklerin standart rutin ile hazırlanan kalibrasyon eğrisinde değerlendirilmesi ile hesaplanmıştır.

\section{Rutin için geri kazanım testi}

Rutin konsantrasyonu bilinen iki ayrı karadut suyu numunesi üzerine bilinen konsantrasyonlardaki rutin standart çözeltilerinden ekleme yapılıp HPLC cihazındaki aynı şartlarda gerçekleştirilen ölçüm ile geri kazanım oranı belirlenmiştir. Bu amaçla, her ekleme seviyesi için altı enjeksiyon yapılmıştır. Gıda proseslerinde kalitede meydana gelen kayıplar daha çok sıfır ve birinci dereceden kinetiğe uygunluk göstermektedir (Labuza ve Riboh, 1982; Labuza, 1984). Bu çalışmada farklı sıcaklık ve sürelerde ısıl işlem uygulamasına bağlı olarak pastörize edilen karadut sularının rutin ve toplam fenolik bileşik içeriğindeki azalmanın kinetiği incelenmiştir. Her iki parametre için kaybın birinci dereceden kinetiğe uygun olduğu tespit edilmiştir. Dolayısıyla elde edilen verilerin hesaplanmasında birinci derece reaksiyonu tanımlayan 1 No.lu eşitlik kullanılmıştır (Arabshahi ve Lund, 1985).

$\ln C=\ln C o-k \cdot t$

\section{Kinetik parametrelerin hesaplanması}

Parçalanma kinetiği için genel hız ifadesi 2 No.lu eşitlik ile tanımlanmaktadır (Labuza ve Riboh, 1982; Kadakal ve Artık, 2008):

Burada;
$-\frac{d[C]}{d t}=k[C]^{m}$

\section{Burada;}

[C]: Dikkate alınan bileşenin nicel değeri,

$k$ : Reaksiyon hız sabiti,

$m$ : Reaksiyonun derecesi,

$t$ : Reaksiyonun gerçekleşme süresi (dk.),

Genel hiz denkleminin entegrasyonundan sonra birinci derece kinetik modele uyarlanmasıyla 3 No.lu eşitlik elde edilir.

$\ln \left(\frac{[C]_{t}}{[C]_{0}}\right)=-k t$

Burada;

$C_{o}$ : Başlangıç rutin veya fenolik madde konsantrasyonu $\left(\mathrm{mg} \mathrm{L}^{-1}\right)$,

$C_{t}$ : Herhangi bir $t$ süresindeki rutin veya toplam fenolik madde konsantrasyonu

$k$ : Reaksiyon hız sabiti $\left(\mathrm{dk}^{-1}{ }^{-1}\right.$,

$t$ : Reaksiyonun gerçekleşme süresi (dk.)

Rutin ve toplam fenolik maddenin sıcaklığa bağımlılığı 4 No.lu eşitlikte gösterilen Arrhenius denklemi ile tanımlanmıştır.

$k=k_{0} \times e^{-E_{a} / R T}$

Bu eşitliğin integrasyonu ile 5 No.lu eşitliğe ulaşılır.

$\ln k=\frac{-E_{a}}{R} \times \frac{1}{T}+\ln k_{0}$

Burada;

$k$ : Reaksiyon hız sabiti,

$k_{0}:$ Frekans faktörü,

$E_{a}$ : Aktivasyon enerjisi (cal mol ${ }^{-1}$ veya $\mathrm{J} \mathrm{mol}^{-1}$ )

$R$ : Gaz sabiti $\left(1.987 \mathrm{cal} \mathrm{mol}^{-1} \mathrm{~K}^{-1}\right.$ veya $8.314 \mathrm{~J} \mathrm{~mol}$

$T$ : Sicaklık (K).

Reaksiyon hız sabitlerinin $(k)$ doğal logaritlaları $(\operatorname{lnk})$ aritmetik skalalı bir grafiğin ordinatına, $\operatorname{lnk}$ değerlerine karşılık gelen sıcaklık $(K)$ değerlerinin 
resiprokali $(1 / T)$ apsise girilerek Arrhenius grafiği denilen lineer bir kurve elde edilmiştir. Regresyon analizi uygulanan kurve yardımıyla elde edilen eğim değerinin gaz sabiti ile çarpılmasıyla aktivasyon enerjisi bulunmuştur.

$Q_{10}$ değeri, aktivasyon enerjisi gibi reaksiyonların sıcaklıktan etkilenme derecelerini gösteren bir parametredir. $Q_{10}$ değerinin hesaplanmasında 6 No.lu eşitlikten yararlanılmıştır (Labuza ve Schmidl, 1985).

$$
Q_{10}=\left(\frac{k_{2}}{k_{1}}\right)^{\frac{10}{T_{2}-T_{1}}}
$$

Burada;

$T$ : Mutlak sıcaklık;

$k_{1}: T_{1}$ sıcaklık derecesindeki hız sabiti,

$k_{2}: T_{2}$ sıcaklık derecesindeki hız sabiti,

Yarılanma süresi $\left(\boldsymbol{t}_{\mathbf{1 / 2}}\right)$

Bir kalite parametresinde \%50 azalışın gerçekleşmesi için geçen süre yarılanma süresi olarak tanımlanır. Birinci dereceden reaksiyonlarda yarılanma 7 No.lu eşitlikle hesaplanır (Labuza, 1984).

$t_{1 / 2}=0.693 / k$

Burada;

$k \quad:$ Reaksiyon hızı sabitidir $\left(\mathrm{dk}^{-1}\right)$,

$t_{1 / 2}$ : Yarılanma süresi (dk.),

\section{Diğer analizler}

Toplam kuru madde (\%), suda çözünür kuru madde $\left({ }^{\circ} \mathrm{Bx}\right), \mathrm{pH}$ ve toplam asitlik (sitrik asit cinsinden) analizlerinde Association of Official Analytical Chemists (AOAC, 1990) metodu kullanılmıştır. Karadut suyundaki toplam şeker miktarı ise Lane-Eynon metoduna göre belirlenmiştir (Cemeroğlu, 1992).

\section{Istatistiki analizler}

Tüm verilerin istatistiksel analizi için $\mathrm{SAS}^{\circledR}$ yazılımı (SAS, 1985) kullanılmıştır. Örnekler arası farkın önemli olduğu durumlarda ortalamalar arası farkı belirlemek için Duncan testi kullanılmıştır.

\section{Araştırma Bulguları ve Tartışma}

Dünya literatüründe beyaz dut, karadut ve yakın türler ile ilgili yapılmış çalışmalar çoğunlukla bu ürünlerin fiziksel ve kimyasal özellikleri üzerinedir. Karadut suyunda rutin ve toplam fenolik madde içeriğinin ısıl parçalanma kinetiği üzerine bir çalışmaya rastlanmamıştır. Ayrıca, dünya literatüründe gıda maddelerinde rutin içeriği ve ısıl parçalanması üzerine yapılan çalışmaların sayısı sınırlı ve çalışmalar çoğunlukla tıp alanındadır. Yapılan bu çalışmanın dünya literatüründeki eksikliği tamamlamak suretiyle literatüre önemli bir katkı sağlama potansiyeli bulunmaktadır.

\section{Kullanılan karadut suyu örneklerinin özellikleri}

Araştırmada kullanılan karadut suyunun \%16.15 toplam kuru madde, $15.16{ }^{\circ} \mathrm{Bx}$ (suda çözünür kuru madde), 3.4 pH, \%0.35 toplam asit ve \%11.50 toplam şeker ihtiva ettiği tespit edilmiştir. Karadut suyunun suda çözünür kurumadde, toplam asit (sitrik asit cinsinden) ve $\mathrm{pH}$ değerlerinin sırasıyla \%11.55-19.04, 1.37-2.24 g $100^{-1} \mathrm{ml}^{-1}$ ve 3.63-4.18 arasında değiştiği bildirilmiştir (Erkaleli ve Dalkılıç, 2016).

\section{HPLC yönteminin analitik karakteristikleri}

Karadut suyunda rutin analizine ilişkin yöntemin doğruluğu ve cihaz hassasiyetinin belirlenmesi amacıyla elde edilen kalibrasyon eğrisi lineerliği, dedeksiyon limiti, geri kazanım ve hassasiyet değerleri Çizelge 2 'de verilmiştir. Rutin için $R$ değeri 0.999, $r^{2}$ değeri ise \%99.82 olarak tespit edilmiştir. Rutinin HPLC cihazında tespit limiti S/N (sinyal/gürültü) değeri üzerinden 0.5 ppm olarak tespit edilmiştir. Cihazın geri kazanım değerlerinin belirlenmesi amacıyla standart ekleme yöntemi kullanılmıştır. Bu amaçla önceden rutin içeriği bilinen örneklere 30 ve 50 $\mathrm{mg} \mathrm{L}^{-1}$ düzeyinde standart rutinden ekleme yapılarak her bir ekleme için cihazdan alınan altı sonuç kaydedilmiştir. 30 ve $50 \mathrm{mg} \mathrm{L}^{-1}$ düzeyindeki 
eklemelerden sırasıyla \%101.5 ve \%102.3, ortalama \%101.9 geri kazanım sağlandığı belirlenmiştir. Metot hassasiyetinin belirlenmesi aynı kimyasalların ve aynı cihazın aynı deneysel koşullar altında aynı örnek üzerinde intra ve intergün testlerinin 6 ölçümle gerçekleştirilmesiyle ortaya konulmuştur. Çalışılan metot için bağıl standart sapma (BSS) değeri \%2.20 olarak tespit edilmiştir. Bilindiği gibi düşük BSS değeri HPLC için hassasiyetin, diğer bir ifade ile sonuçlar açısından değişken olmayan veri göstergesidir.

Karadut suyunda rutin ve toplam fenolik bileşiklerin ısıl parçalanması

Karadut suyunda rutin ve toplam fenolik madde içeriğinin ısıl parçalanma kinetiğinin belirlenmesi için $70,80,90$ ve $95{ }^{\circ} \mathrm{C}$ sıcaklık ve (0, $5,10,15,20,25$ ve $30 \mathrm{dk}$.) süre seçilerek her iki parametre için kinetik çalışmaya ait veriler elde edilmiştir. Şekil 1 ve 2'de görüldüğü gibi, rutin ve toplam fenolik bileşiklerin parçalanması birinci dereceden kinetik modele göre gerçekleşmiştir. Isıtma sıcaklığı ve süresi arttıkça, rutin ve toplam fenolik maddedeki parçalanma artış göstermiştir. Şekil 1 ve Şekil 2'den görüldüğü gibi karadut suyunda rutin ve toplam fenolik madde için 0.98 'in üzerindeki korelasyon katsayısı birinci dereceden parçalanma kinetiğine uygunluğu göstermektedir. Bilindiği gibi sıfır veya birinci dereceden reaksiyonlar arasındaki istatistiksel farklılıklar önemsiz olabilmektedir (Van Boekel, 2008). Diğer yandan karadut suyunda rutin ve toplam fenolik bileşiklerin ısıl parçalanması hakkında yayınlanmış bir veriye rastlanamadığından sonuçlar literatür bilgileriyle karşılaştırılamamıştır.

Karadut suyunda rutin ve toplam fenolik maddenin ısıl parçalanma kinetiğine ilişkin hız sabitleri $(k)$ ve yarı ömür süreleri $\left(t_{1 / 2}\right)$ Çizelge 2'de gösterilmiştir. Isıl parçalanmaya ilişkin hız sabitinin belirlemesi için In $\left(C / C_{0}\right)-t$ grafiğinin doğrusal eğimi kullanılmıştır.

Çizelge 2. Karadut suyunda rutin analizine ait kalibrasyon eğrisi lineerliği, dedeksiyon limiti, geri kazanım ve hassasiyet değerleri.

Table 2. Linearity of standard curve and detection limit, recovery and precision of method for determination of rutin in black mulberry

\begin{tabular}{|c|c|c|c|c|c|c|c|c|}
\hline \multirow{3}{*}{$\begin{array}{l}\text { Vitamin } \\
\text { Vitamin }\end{array}$} & $\begin{array}{l}\text { Lineer aralık } \\
\qquad\left(\mathrm{mg} \mathrm{L}^{-1}\right)\end{array}$ & & & $\begin{array}{c}\text { Dedeksiyon } \\
\text { limiti }\left(\mathrm{mg} \mathrm{L}^{-1}\right)\end{array}$ & $\begin{array}{c}\text { Başlangıç } \\
\text { değer }\left(\mathrm{mg} \mathrm{L}^{-1}\right)\end{array}$ & $\begin{array}{c}\text { Illave sonrası } \\
\text { değer }\left(\mathrm{mg} \mathrm{L}^{-1}\right)^{\mathrm{a}, \mathrm{b}}\end{array}$ & $\begin{array}{c}\text { Geri } \\
\text { kazanım (\%) }\end{array}$ & Hassasiyet \\
\hline & \multirow[t]{2}{*}{$\begin{array}{l}\text { Linear range } \\
\qquad\left(m g L^{-1}\right)\end{array}$} & \multirow[t]{2}{*}{$R$} & \multirow[t]{2}{*}{$r^{2}$} & \multirow[t]{2}{*}{$\begin{array}{l}\text { Detection limit } \\
\qquad\left(m g L^{-1}\right)\end{array}$} & \multirow[t]{2}{*}{$\begin{array}{l}\text { Initial value } \\
\qquad\left(m g L^{-1}\right)\end{array}$} & $\begin{array}{c}\text { Content after } \\
\text { addition }\left(\mathrm{mg} \mathrm{L}^{-1}\right)^{a, b}\end{array}$ & Recovery (\%) & Precision \\
\hline & & & & & & & $\begin{array}{c}\text { Ort. } \\
\text { Average }\end{array}$ & $\begin{array}{l}\text { B.S.S. (\%) } \\
\text { R.S.D. (\%) }\end{array}$ \\
\hline \multirow{2}{*}{$\begin{array}{l}\text { Rutin } \\
\text { Rutin }\end{array}$} & \multirow{2}{*}{$5.0-250.0$} & \multirow{2}{*}{0.999} & \multirow{2}{*}{99.82} & \multirow{2}{*}{0.5} & $248.6 \pm 0.9$ & $305.5 \pm 0.13$ & $102.3 \pm 0.54$ & \multirow{2}{*}{2.20} \\
\hline & & & & & $248.6 \pm 0.9$ & $282.9 \pm 0.20$ & $101.5 \pm 0.60$ & \\
\hline
\end{tabular}

a: $50 \mathrm{mg}$ rutin ilavesi; $\mathrm{b}: 30 \mathrm{mg}$ rutin ilavesi; c:Ortalama \pm standard sapma.

$a$ :addition of $50 \mathrm{mg}$ rutin, $b$ :addition of $30 \mathrm{mg}$ rutin; $c$ :Mean \pm standard deviation.

B.S.S : Bağıl standart sapma R.S.D: Relative standard deviation

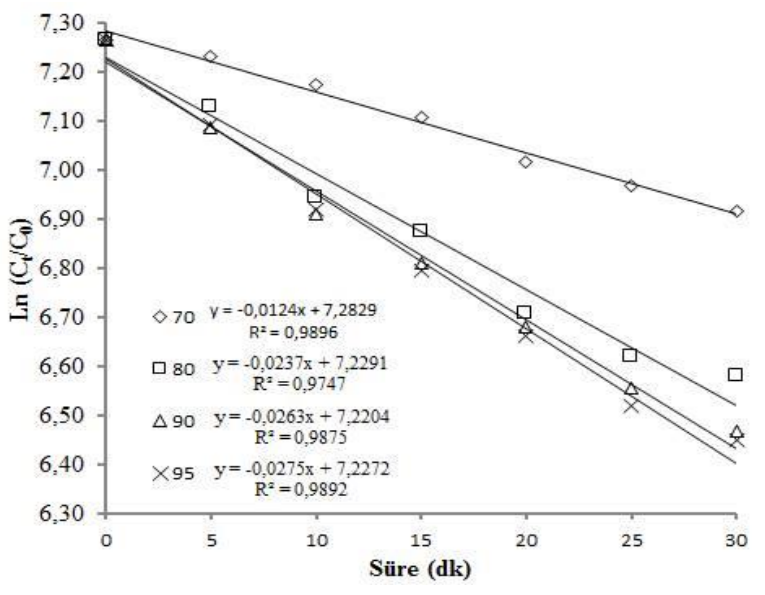

Şekil 1. Karadut suyunda toplam fenolik bileşenlerin farklı sıcaklıklardaki birinci dereceden ısıl parçalanma kinetiği.

Figure 1. First order kinetic of TPC thermal degradation at different temperatures in black mulberry

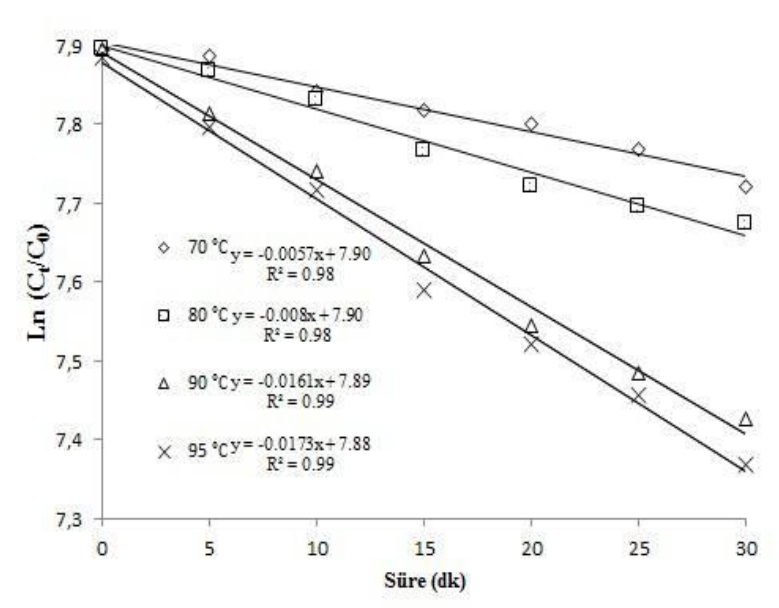

Şekil 2. Karadut suyunda rutinin farklı sıcaklıklardaki birinci dereceden ısıl parçalanma kinetiği.

Figure 2. First order kinetic of rutin thermal degradation at different temperatures in black mulberry 
Karadut suyunda rutin ve toplam fenolik madde açısından sıcaklığın aktivasyon enerjisi $\left(E_{\mathrm{a}}\right)$, reaksiyon hız sabiti $(k), Q_{10}$ ve yarılanma süresi $\left(t_{1 / 2}\right)$ üzerine etkisine ait veriler Çizelge 3 'de verilmiştir. Rutin ve toplam fenolik maddenin hız sabitleri, sıcaklığın artmasıyla artmıştır. Bu sonuç, rutin ve toplam fenolik maddenin bozunmalarının sıcaklığa bağımlı olduğunu göstermektedir. Rutin içeriği toplam fenolik maddeye göre daha az bozunmaya meyillidir. Rutinin hız sabiti, $70-80{ }^{\circ} \mathrm{C}$ ve $90-95{ }^{\circ} \mathrm{C}$ arasında sıcaklık artışıyla artmaktadır. Bununla birlikte artış önemli ölçüde 80 ila $90^{\circ} \mathrm{C}$ arasında belirlenmiştir. Analiz sonuçlarından, rutinin $95{ }^{\circ} \mathrm{C}$ 'de daha yüksek $\mathrm{k}$ değerine sahip olduğu, dolayısıyla diğer sıcaklık değerlerine göre daha hızlı bir bozunmaya uğradığı görülmüştür. Buna karşılık, toplam fenolik maddenin hız sabiti,
$70-80{ }^{\circ} \mathrm{C}$ arasında belirgin bir şekilde, $80-90{ }^{\circ} \mathrm{C}$ ve $90-95{ }^{\circ} \mathrm{C}$ arasında ise az bir artış göstermiştir. Rutin ve toplam fenolik maddenin $\mathrm{k}$ değerleri 70 $95{ }^{\circ} \mathrm{C}$ arasındaki sıcaklıklarda sırasıyla $5 \times 10^{-3}$ $16 \times 10^{-3}$ ve $10 \times 10^{-3}-28 \times 10^{-3}$ değerleri arasında değişmiştir (Çizelge 3).

Çizelge 3 'te gösterildiği gibi, sıcaklığın artması ile rutin ve toplam fenolik madde için yarı ömür süreleri $\left(t_{1 / 2}\right)$ azalmıştır. Bu sonuç, rutin ve toplam fenolik bileşiklerin yüksek sıcaklıklarda daha hızlı parçalandığına işaret etmektedir. Rutin, aynı sıcaklık değerleri baz alınarak karşılaştırıldığında toplam fenolik maddeye göre daha yüksek $t_{1 / 2}$ değerine sahiptir. Bu sonuç karadut suyunda aynı sıcaklıklarda rutinin toplam fenolik madde ile karşılaştırıldığında daha yüksek termal stabiliteye sahip olduğunu göstermektedir.

Çizelge 3. Karadut suyunda rutin ve toplam fenolik açısından sıcaklığın aktivasyon enerjisi $\left(E_{A}\right)$, reaksiyon hız sabiti $(k), Q_{10}$ ve yarılanma süresi $\left(t_{1 / 2}\right)$ üzerine etkisi.

Table 3. Effect of temperature on the activation energy $(E a)$, reaction rate constant $(k), Q_{10}$ and half-life $\left(t_{1 / 2}\right)$ values of rutin and and TPC.

\begin{tabular}{|c|c|c|c|c|c|c|c|}
\hline \multirow{2}{*}{$\begin{array}{l}\text { Parametre } \\
\text { Parameter }\end{array}$} & \multirow{2}{*}{$T(C)$} & \multirow{2}{*}{$k 10^{3}(1 / \mathrm{dk} .)}$. & \multirow{2}{*}{$t_{1 / 2}(\mathrm{dk} .)}$. & \multicolumn{3}{|c|}{$Q_{10}$} & \multirow[t]{2}{*}{$E_{a}(\mathrm{~kJ} / \mathrm{mol})$} \\
\hline & & & & $70-80 \mathrm{C}$ & $80-90 \mathrm{C}$ & $90-95 \mathrm{C}$ & \\
\hline & 70 & 5 & 138.63 & & & & \\
\hline Rutin & 80 & 8 & 86.64 & & & & \\
\hline \multirow[t]{3}{*}{ Rutin } & 90 & 14 & 49.51 & 1.6 & 1.75 & 1.07 & 50.53 \\
\hline & 95 & 16 & 43.32 & & & & \\
\hline & 70 & 10 & 138.63 & & & & \\
\hline \multirow[t]{3}{*}{$\begin{array}{l}\text { TFM } \\
T P C\end{array}$} & 80 & 25 & 86.64 & 1.92 & 1.13 & 1.08 & 34.89 \\
\hline & 90 & 26 & 49.51 & & & & \\
\hline & 95 & 28 & 43.32 & & & & \\
\hline
\end{tabular}

TFM: Toplam fenolik madde TPC: Total phenolic compound

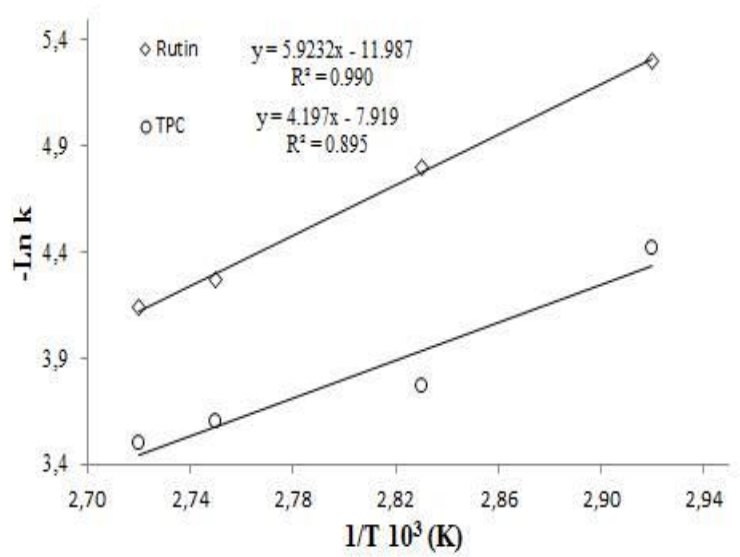

TPC: Topam fenolik bileşik, TPC: Total phenolic compound

Şekil 3. Karadut suyunda farklı sıcaklık uygulamasıyla toplam fenolik bileşikler ve rutinin ısıl parçalanmasına ilişkin arrhenius eğrileri

Figure 3. Arrhenius plots for degradation of TPC and rutin in black mulberry nectar during heating
Hız sabitlerinin logaritması mutlak sıcaklık değerlerinin resiprokaline karşı bir lineer koordinat sistemine işlendiğinde, lineer eğrinin eğimi $E_{a} /_{R}$ değerini vermektedir (Şekil 3). Karadut suyundaki rutin ve toplam fenolik maddenin parçalanmasına ilişkin aktivasyon enerjileri, $70-95^{\circ} \mathrm{C}$ arasındaki sıcaklıklarda farklılık göstermektedir. Tüm sıcaklık değerlerinde toplam fenolik maddeye göre rutin daha yüksek aktivasyon enerji değerine sahiptir. Bu sonuç, rutinin toplam fenolik maddeye kıyasla Isıl parçlanmaya karşı daha dayanıklı olduğunu göstermektedir. Toplam fenolik madde ve rutinin ısıl parçalanması için aktivasyon enerjileri sırasıyla 
34.83 ve $50.53 \mathrm{~kJ} \mathrm{~mol}^{-1}$ olarak hesaplanmıştır. Bir reaksiyonun yüksek aktivasyon enerjisi, bu reaksiyonun sıcaklık değişimine çok duyarlı olduğunu gösterir. Bu nedenle karadut suyunun rutin ve toplam fenolik madde içeriği, $95^{\circ} \mathrm{C}^{\prime}$ de 70 ${ }^{\circ} \mathrm{C}$ 'ye göre ısıl parçalanmaya karşı daha hassastır.

Karadut suyunda $70-95 \quad{ }^{\circ} \mathrm{C}$ sıcaklıkları arasındaki rutin ve toplam fenolik maddeye ilişkin $Q_{10}$ değerleri Çizelge 3 'te gösterilmiştir. Karadut suyunda $70-95{ }^{\circ} \mathrm{C}$ arasındaki sıcaklıklarda her 10 ${ }^{\circ} \mathrm{C}^{\prime}$ lik artış için $Q_{10}$ değerleri farklılık göstermiştir. Rutin ve toplam fenolik madde için en yüksek $Q_{10}$ değerleri sırasıyla $80-90{ }^{\circ} \mathrm{C}$ ve $70-80{ }^{\circ} \mathrm{C}$ aralığında elde edilmiştir. $\mathrm{Bu}$ sonuç, rutinin $\mid$ sıl parçalanmasının $80-90{ }^{\circ} \mathrm{C}$, toplam fenolik bileşiklerin parçalanmasının ise $70-80{ }^{\circ} \mathrm{C}$ arasındaki sıcaklıklarda daha fazla olduğunu, diğer sıcaklık aralıklarında ise rutin ve toplam fenolik bileşiklerin sıcaklık değişimlerinden çok az etkilendiğini göstermektedir.

\section{Sonuçlar}

Bu çalışma çeşitli sıcaklık ve sürelerde ısıl işlem uygulanan karadut suyunda rutin ve toplam fenolik maddenin ısıl parçalanması ilişkin bir ilktir. Karadut suyunda rutin ve toplam fenolik maddenin ısıl parçalanma kinetiği birinci dereceden kinetik modele göre gerçekleşmektedir. Sıcaklık ve ısıtma süresi arttıkça, incelenen bileşiklerin bozunma hızı artmıştır. Karadut suyunun uzun süreli ısıl işleme tabi tutulmasında rutin ve toplam fenolik madde içeriğindeki kaybın azalması anlamında en iyi sıcaklık $70{ }^{\circ} C^{\prime}$ dir. Karadut suyu üretimi gerçekleştiren işletmeler açısından, üretim sürecinde rutin ve toplam fenolik madde miktarının kontrolünde bu çalışmanın sonuçları faydalı olacaktır. Ayrıca, karadut ve karadut suyundaki rutin ve toplam fenolik maddenin Isıl parçalanmasına ilişkin literatürde bir çalışma yoktur. Bu nedenle, bu çalışma gelecekteki çalışmalara da ışık tutacaktır.

\section{Ekler}

Bu çalışma Pamukkale Üniversitesi Bilimsel Araştırma Projeleri Birimi [proje no: 2012FBE007] tarafından desteklenmiştir. Bu çalışma Cemre SERNIKLI'nin “Karadut (Morus nigrara) suyunda toplam fenolik madde ve suda çözünen vitaminlerin ısıl parçalanma kinetiği” adlı yüksek lisans tezinden üretilerek hazırlanmıştır.

\section{Çıkar Çatışması Beyanı: Makale yazarları} aralarında herhangi bir çıkar çatışması olmadığını beyan ederler.

\section{Kaynaklar}

AOAC, (1990). Official Methods of Analysis. $15^{\text {th }}$ ed. Association of Official Analytical Chemists, Washington, DC, USA.

Arabshahi, A., \& Lund, D. B. (1985). Considerations in calculating kinetic parameters from experimental data. Journal of Food Process Engineering, 7(4), 239251.

Attia, T. Z. (2016). Simultaneous determination of rutin and ascorbic acid mixture in their pure and combined dosage form. Spectrochimica Acta Part A: Molecular and Biomolecular Spectroscopy, 169, 82-86.

Avila, I. M. L. B., \& Silva, C. L. M. (1999). Modelling kinetics of thermal degradation of colour in peach puree. Journal of Food Engineering, 39(2), 161-166.

Boranbayeva, T., Karadeniz, F., \& YIlmaz, E. (2014). Effect of storage on anthocyanin degradation in black mulberry juice and concentrates. Food and Bioprocess Technology, 7(7), 1894-1902.

Cemeroğlu, B. (1992). Meyve ve sebze işleme endüstrisinde temel analiz metotları (Basic analysis methods in fruit and vegetable processing industry). Biltav Üniversite Kitapları Serisi (University Book Series,. Biltav edition) No, 02-2.

Cho, C. M., Ko, J. H., \& Cheong, W. J. (2000). Simultaneous determination of water-soluble vitamins excreted in human urine after eating an overdose of vitamin pills by a HPLC method coupled with a solid phase extraction. Talanta, 51(4), 799-806.

Daigle, D. J., \& Conkerton, E. J. (1988). Analysis of flavonoids by HPLC: an update. Journal of liquid chromatography, 11(2), 309-325.

Davis, P. H. (1970). Flora of Turkey and the East Aegean Islands. Vol. 3. Flora of Turkey and the East Aegean Islands. Vol. 3.

Dincer, C., Tontul, I., \& Topuz, A. (2016). A comparative study of black mulberry juice concentrates by thermal evaporation and osmotic distillation as influenced by storage. Innovative Food Science \& Emerging Technologies, 38, 57-64.

Ercisli, S., \& Orhan, E. (2008). Some physico-chemical characteristics of black mulberry (Morus nigra L.) 
genotypes from Northeast Anatolia region of Turkey. Scientia Horticulturae, 116(1), 41-46.

Erkaleli, Z.Ö., Dalkiliç, Z. (2006). Uşak ili Ulubey ilçesinde yetişen karadutlarin (Morus nigra L.) Morfolojik, Fenolojik ve Pomolojik Özelliklerinin Belirlenmesi. Adnan Menderes Üniversitesi Ziraat Fakültesi Dergisi, 13(1), 89-106.

Fazaeli, M., Hojjatpanah, G., \& Emam-Djomeh, Z. (2013). Effects of heating method and conditions on the evaporation rate and quality attributes of black mulberry (Morus nigra) juice concentrate. Journal of Food Science and Technology, 50(1), 35-43.

Gecer, M. K., Akin, M., Gundogdu, M., Eyduran, S. P., Ercisli, S., \& Eyduran, E. (2016). Organic acids, sugars, phenolic compounds, and some horticultural characteristics of black and white mulberry accessions from Eastern Anatolia. Canadian Journal of Plant Science, 96(1), 27-33.

Gerasopoulos, D., \& Stavroulakis, G. (1997). Quality characteristics of four mulberry (Morus sp) cultivars in the area of Chania, Greece. Journal of the Science of Food and Agriculture, 73(2), 261-264.

Gökalp, H. Y., Certel, M., \& Nas, S. (1992). Biyokimya: Temel yapılar ve kavramlar.

Güngor, N., \& Sengul, M. (2008). Antioxidant activity, total phenolic content and selected physicochemical properties of white mulberry (Morus alba L.) fruits. International Journal of Food Properties, 11(1), 44-52.

İnanç, A. L., \& Yüksel, D. (2018). Ihlamur bitkisinin (Tilia cordata) katı-sıvı ekstraksiyonunda toplam fenolik madde kinetiğinin matematiksel modellenmesi. Harran Tarım ve Gıda Bilimleri Dergisi, 22(1), 12-20.

Kadakal, Ç., \& Artik, N. (2008). Degradation kinetics of ergosterol in tomato paste serum. European Food Research and Technology, 227(3), 683-688.

Kamalakkannan, N., \& Prince, P. S. M. (2006). Antihyperglycaemic and antioxidant effect of rutin, a polyphenolic flavonoid, in streptozotocin-induced diabetic wistar rats. Basic \& Clinical Pharmacology \& Toxicology, 98(1), 97-103.

Karaman, H. T., Küskü, D.Y., \& Söylemezoğlu, G. (2020). Bazı üzüm (Vitis vinifera L.) çeşitlerine ait salkım iskeletlerinin toplam fenolik bileşik ve transresveratrol düzeyleri. Harran Tarım ve Gıda Bilimleri Dergisi. 24(2), 222-228.

Kicel, A., Owczarek, A., Michel, P., Skalicka-Woźniak, K., Kiss, A. K., \& Olszewska, M. A. (2015). Application of HPCCC, UHPLC-PDA-ESI-MS3 and HPLC-PDA methods for rapid, one-step preparative separation and quantification of rutin in Forsythia flowers. Industrial Crops and Products, 76, 86-94.

Korkmaz, A., \& Kolankaya, D. (2010). Protective effect of rutin on the ischemia/reperfusion induced damage in rat kidney. Journal of Surgical Research, 164(2), 309315.

Kuntić, V., Malesěev, D., Radović, Z., \& Vukojević, V. (2000). Spectrophotometric investigation of the complexing reaction between rutin and titanyloxalate anion in $50 \%$ ethanol. Monatshefte für Chemie/Chemical Monthly, 131(7), 769-777.

Kuntić, V., Pejić, N., Ivković, B., Vujić, Z., Ilić, K., Mićić, S., \& Vukojević, V. (2007). Isocratic RP-HPLC method for rutin determination in solid oral dosage forms. Journal of pharmaceutical and biomedical analysis, 43(2), 718-721.

Labuza, T. P., \& TP, L. (1982). Theory and application of Arrhenius kinetics to the predication of nutrient losses in foods.

Labuza, T. P. (1984). Application of chemical kinetics to deterioration of foods. Journal of Chemical Education, 61, 348-358.

Labuza, T. P., \& Schmidl, M. K. (1985). Accelerated shelf-life testing of foods. Food Technology, 39(9), 57-62.

Lee, W., Ku, S. K., \& Bae, J. S. (2012). Barrier protective effects of rutin in LPS-induced inflammation in vitro and in vivo. Food and Chemical Toxicology, 50(9), 3048-3055.

Leite, J. P. V., Rastrelli, L., Romussi, G., Oliveira, A. B., Vilegas, J. H., Vilegas, W., \& Pizza, C. (2001). Isolation and HPLC quantitative analysis of flavonoid glycosides from Brazilian beverages (Maytenus ilicifolia and M. aquifolium). Journal of Agricultural and Food Chemistry, 49(8), 3796-3801.

Li, W., \& Fitzloff, J. F. (2001). High performance liquid chromatographic analysis of St. John's wort with photodiode array detection. Journal of Chromatography B: Biomedical Sciences and Applications, 765(1), 99-105.

Maskan, A., Kaya, S., \& Maskan, M. (2002). Effect of concentration and drying processes on color change of grape juice and leather (pestil). Journal of Food Engineering, 54(1), 75-80.

Menghinello, P., Cucchiarini, L., Palma, F., Agostini, D., Dacha, M., \& Stocchi, V. (1999). Simultaneous analysis of flavonoid aglycones in natural products using an RP-HPLC method.Journal of Liquid Chromatography \& Related Technologies, 22(19), 3007-3018.

Nakamura, Y., Watanabe, S., Miyake, N., Kohno, H., \& Osawa, T. (2003). Dihydrochalcones: evaluation as novel radical scavenging antioxidants. Journal of Agricultural and Food Chemistry, 51(11), 3309-3312.

Nizamlıoğlu, N., \& Nas, S. (2010). The phenolic compounds in vegetables and fruit; structures and their importance. Electronic Journal of Food Technologies, 5(1), 20-35.

Pang, N., Malike, D., \& Liu, H. (2009). Simultaneous determination of main bioactive components in Rosa multiflora Thunb. and their fragmentation study by LC-MS. Chromatographia, 70(7-8), 1253.

Sánchez-Salcedo, E. M., Mena, P., García-Viguera, C., Hernández, F., \& Martínez, J. J. (2015). (Poly) phenolic compounds and antioxidant activity of white (Morus alba) and black (Morus nigra) mulberry leaves: Their potential for new products rich in phytochemicals. Journal of Functional Foods, 18, 1039-1046.

SAS Institute. (1985). SAS user's guide: Statistics (Vol. 2). Sas Inst.

Tanner, H., \& Brunner, H. R. (1979). Getränke-Analytik: Untersuchungsmethoden für die Labor-und Betriebspraxis. Verlag Heller Chemie-und Verwaltungsgesellschaft, \$ c1987.

Tarko, T., Duda-Chodak, A., Satora, P., Sroka, P., Pogoń, P., 
\& Machalica, J. (2014). Chaenomeles japonica, Cornus mas, Morus nigra fruits characteristics and their processing potential. Journal of Food Science and Technology, 51(12), 3934-3941.

Tomas, M., Toydemir, G., Boyacioglu, D., Hall, R., Beekwilder, J., \& Capanoglu, E. (2015). The effects of juice processing on black mulberry antioxidants. Food Chemistry, 186, 277-284.

Van Boekel, M. A. (2008). Kinetic modeling of reactions in foods. CRC press.
Venkatesh Kumar, R., \& Chauhan, S. (2008). Mulberry: life enhancer. Journal of Medicinal Plants Research, 2(10), 271-278.

Yıldırım, S., Kadıoğlu, A., Sağlam, A., \& Yaşar, A. (2017). Determination of phenolic acids and rutin in Heliotropium thermophilum by high-performance liquid chromatography with photodiode array detection. Instrumentation Science \& Technology, 45(1), 35-48. 